\title{
Lifting the veil on the government's regulatory agenda for the social work profession in Aotearoa New Zealand
}

\author{
Howard Randal, New Zealand
}

\begin{abstract}
INTRODUCTION: The article discusses the two contrasting agendas evident when statutory registration for social workers in Aotearoa New Zealand was introduced in 2003 - that of the professional association and that of the government.

METHOD: The approach taken draws on a longitudinal research study of the aspirations for statutory registration held by a sample of members of the Aotearoa New Zealand Association of Social Workers (ANZASW). In addition, the motives behind the professionalisation strategy introduced by the principal government social work service are examined and analysed applying Foucault's concept of governmentality.
\end{abstract}

FINDINGS: The qualitative analysis of the data shows that the profession, although aspiring to having some role in statutory registration, also held concerns about its implications. By way of contrast, the professionalisation strategy adopted by the government social work service shows it was driven by public service performance, fiscal and risk management imperatives.

CONCLUSIONS: The application of the Foucauldian theory of governmentality to the data and findings shows that the introduction of statutory registration is a manifestation of the managerial and statutory controls adopted by government and a means of governmentality. This has resulted in the government holding the upper hand in providing public accountability for social work practice thereby perpetuating its hold over the profession with the risk that the ANZASW is left in its wake.

KEYWORDS: social worker, statutory registration, profession, governmentality, regulation, risk management

AOTEAROA

NEW ZEALAND SOCIAL WORK 30(1), 20-31.

CORRESPONDENCE TO: Howard Randal

howard.randal@xtra.co.nz
This article examines, from three different perspectives, the context in which statutory registration for social workers was first introduced in 2003. The first is that of a sample of members of the New Zealand Association of Social Workers Inc. (NZASW, later ANZASW) whose views and aspirations for statutory registration were obtained prior to its introduction and their subsequent reflections 18 years later. The second perspective accounts for the imperatives that had arisen for the credentialing of social workers in the New Zealand Children and Young Persons Service (NZCYPS), a government social work service. These imperatives became instrumental in statutory registration being introduced, made possible through the political sponsorship of the New Zealand Labour Party (NZLP) in forming a new government in 1999. Thirdly, the 
Foucauldian socio-political explanation of governmentality and other insights are offered as a basis for examining the motives and agenda held by the government regarding statutory registration for social workers. The article concludes by examining the consequences of statutory registration, the government's tight rein on social work practice in Aotearoa New Zealand and reflections on what this means for the social work profession.

\section{The professional association and statutory registration}

The assertion was made at the inaugural conference of the NZASW in 1964 that "there is now a recognised body of practice and theory that constitutes the profession of social work" and that "social worker" had become an acceptable designation (McCreary, 1964, p. 3). This signalled the advent of the NZASW as the professional body for social workers in Aotearoa New Zealand with membership based on meeting the criteria of working in a social work role for an approved social services agency, working in an approved category of employment or having completed an approved course of professional social work training (NZASW, 1964, § 7). This remained the basis for full membership for the following 25 years. By 1989, with competency certification introduced, the basis for gaining full membership of the association finally became standardised with core practice competencies identified that reflected adherence to its code of ethics and consistency with the bicultural identity for social work in Aotearoa New Zealand (Interim Board of Competency, 1990). And so a process of professional self-regulation (1990) was established. Within those 25 intervening years members had hotly debated the pros and cons and implications of professional status, elitism, and whether membership should be determined on the basis of educational qualification or some other criteria as well as the ramifications for social work should the status of registration be sought (Fraser \& Briggs, 2016; Hessey,
1983; Hunt, 2016; C. Jones, 1979; P. Jones, 1974; NZASW, 1976, 1978, 1981a, 1981b, 1984;).

However, despite the polarisation amongst members, the association emerged with its professional identity intact and its widely accepted and recognised system of selfregulation became the cornerstone for its lobbying for statutory registration in 2000 (Beddoe \& Randal, 1994; Corrigan et al., 1999; Randal, 1997).

\section{The longitudinal study, 1996-2014}

In 1996, as part of a University of Otago approved research project, a sample of members of the association had been interviewed regarding the prospect of statutory registration being introduced and the role the association might have in that. University of Otago research and ethical approval, including consultation with the University of Otago Ngāi Tahu Research Consultation Committee, was subsequently granted in 2014 for the qualitative data gathered in 1996 to become the foundation of a longitudinal study and a sampling frame drawing on the original sample. This involved re-interviewing the reconstituted sample for their reflections on the consequences of the introduction of statutory registration in 2003. In addition, the government minister, who sponsored the introduction of the legislation, and the manager of a project undertaken by the Ministry of Social Policy to provide a discussion paper on statutory registration, were also interviewed. A qualitative analysis, using NVivo (QSR International) software, was conducted of the semi-structured interviews of all respondents interviewed in 1996 and 2014. An iterative process was used to identify and code the emergent key themes within the two sets of data collected, thereby providing a unique longitudinal and historical view of the introduction of statutory registration from the perspective of a sample of association members. This provided the primary data for a research study completed in 2017 (Randal, 2018). The opportunity was taken to consider the data at a broader theoretical level given the 
purpose of statutory registration to regulate the behaviour of a professional through instruments of assessment, monitoring and accountability established by a statutory authority. A theoretical framework was developed for this purpose. Underpinning this was the premise that there were significant implications for both the profession and the professional when their previously self-regulated profession became subject to statutory regulation. The writings of Foucault in relation to governmentality (discussed later) became central to forming this framework including the subordination of a profession to the state through statutory registration and, in particular, how this transcends the role of social work with communities, families and individuals (Chambon, 1999; Gilbert \& Powell, 2010; Healy, 2000; Nadesan, 2008; Pitt, 2005; Powell, 2014).

\section{The prospect of statutory registration, 1996}

The aspirations and reservations expressed by the sample of association members in 1996 about the prospect of statutory registration varied. On the positive side was the consistency and accountability it was believed statutory registration would offer in respect of the protection of clients against poor practice. It could also make compulsory for social workers everything that the association already provided through its selfregulatory processes - adherence to a code of ethics, regular assessments of competency to practise and procedures for addressing complaints about a social worker's practice. This would thus strengthen social work's professional standing, identity and reputation in an environment where greater importance was becoming attached to credentialing, accreditation and certification. The view was also put that social workers felt uncomfortable not being a registered profession or not required to hold compulsory membership with a standard-setting body (Randal, 2018).

There were also concerns expressed regarding the possible impact statutory registration could have for Māori and being marginalised by the process. And just as it had been aired through the years of earlier debate within the association, concern continued to be expressed that statutory registration would foster social work's identification with professional elitism, further distancing social work from the best interests of its client community. There was also one forthright assertion against any form of statutory power being exercised over the profession (2018).

I'm not for a statutory registration. Why? Power. The minute the State authorises a group to be, it gives it the power and it backs the power by statutory authority of an Act of Parliament. I do not believe that one should ever define in law who a social worker is and that it should deny anybody the right to use the term should they choose to do so. (D, 1996)

For some, statutory registration also raised the possibility of it gate-keeping entry into the profession, the inherent self-interest that signals, and the risk of social work becoming the antithesis of what it stands for. Options of statutory registration being embedded as a regulatory arm of the association or, alternatively, as a separate and independent entity so as to not prejudice the association's professional independence, were considered (Randal, 2018). Regardless, it was assumed that association membership would become a precondition for statutory registration as should competency assessment, adherence to its code of ethics and evidence of continuing professional development. Not all believed a recognised qualification was essential. Concerns expressed included the displacement of the association's professional custodianship to a governmentappointed legislative body that would be subject to political influence and would work to an agenda not necessarily shared by social workers (Randal, 2018).

The sample of members interviewed in 1996 was clearly not unanimous on the prospect of statutory registration and its possible form, let alone what might be the 
government's agenda. In many respects the views were in the same league and mirrored the arduous and often heartfelt, but worthy debates the association had witnessed and facilitated over the preceding 30 years (Randal, 2018). History, of course, now tells us that the association ultimately supported the introduction of statutory registration (Beddoe \& Randal, 1994; Corrigan et al., 1999; Randal, 1997). For most of those interviewed in 1996 it was expected that this would signal the association's completion of the process begun in 1964, finally becoming a fully-fledged regulating body sanctioned by government, and thereby a typically regulated profession (Balthazard, 2016).

However, the reality was that, around that time, membership of the ANZASW numbered only 698 (Blagdon, Taylor, \& Keall, 1994) and represented only a small proportion of those who identified as social workers. Whereas the pursuit of statutory registration by the ANZASW can be seen as a natural aspiration for a professional body as it seeks to embody the multiple functions in achieving professional status (Balthazard, 2016; Matarazzo, 1977), different logics apply in respect of a government department seeking the same ends.

\section{NZCYPS and its professionalisation strategy}

The ANZASW was not alone with a vested interest in the status of social work as a profession and the desire to have in place measures that provide assurances and protection regarding practice. As the predominant employer of social workers in health and welfare ministries, the government also had a significant role.

In 1989, the government agency responsible for providing social work services for children and young persons, NZCYPS, faced greater public scrutiny and accountability as it implemented new legislation aimed to devolve services to iwi and community (Children, Young Persons, and Their Families Act, 1989 [CYPF Act, 1989]). As a business unit of the Department of Social Welfare (DSW), NZCYPS was driven by doctrines of risk management and fiscal responsibility typical of the new public management model (NPM) applied to the public service (Hood, 1991). NPM emerged as an administrative doctrine in the 1980s with new business ideas and management models borrowed from the private sector introduced to the public sector to have it more accountable, results-oriented and therefore, supposedly, more businesslike. It also emphasised the centrality of citizens as customers/clients of public sector services (Harris, 2003; Hood \& Scott, 2000). The doctrine of NPM was clearly evident in Te Ara Hou (The New Path), the Social Work Development Plan developed by the Principal Social Worker Unit of DSW to prepare NZCYPS social workers as they adapted to the new Act (Keall, Te KowhaiRennie, \& Quivooy, 1989). The plan laid down the accountabilities of social workers to their managers, the practice standards expected of them to ensure accountability to clients under the Act and the corporate tasks and outputs set for management to raise the practice standards of social work in NZCYPS (1989, p. 9ff). As a very management-centric document there was no hint of fostering professional aspirations for social workers, let alone supporting their affiliation to their professional body. Some therefore regarded NZCYPS social workers in a less-thanprofessional light.
They [NZCYPS] aren't "social work" and they need to be told that very firmly that they're not. If we, social work, the profession gets captured by one agency we're done for, in terms of any independence, any sort of social justice. If we get overtaken by basically an instrumentalist bureaucratic model then we're finished. (M, 1996)

Commentators on the professions, such as Howe (1980) and Anleu (1992), have reflected on the reduced autonomy of professionals employed within the public domain, the bureaucratic bias of their 
supervision and the inevitable tension arising from their dual duty of care to clients on the one hand, and their duty to the state as public servants.

In 1990, at the behest of the government, the role and performance of NZCYPS became subject to a review as part of the wider ministerial review of the CYPF Act 1989. The resultant report identified critical deficits in the overall professional capacity of departmental social workers, relative to competencies, qualifications and training (Mason, 1992). An analysis of the development of the CYPF Act 1989 was also undertaken by Cockburn (1994) regarding the "enormity of the value shift that took place" (1994, p. 86) between it and "the former monocultural Children and Young Persons Act, 1974" (1994, p. 86) and, at the same time, noting the impact and expectations that the new State Sector Act 1988 and Public Finance Act 1989 placed on social work management. The Mason Report (Mason, 1992) prompted the government to better resource the CYPF Act 1989 specifically to up-skill social work staff to meet the objects and principles of the Act (Cockburn, 1994). In response, NZCYPS introduced a professionalisation strategy that required departmental social workers to attain a social work qualification and undertake regular competency assessments. This strategy was subsequently evaluated for its return on investment to the government (Coopers \& Lybrand, 1995). The fiscally driven evaluation also alluded to the relatively low professional status of social workers when compared with other professions. The evaluation commented on the fact that there was no independent statutory body overseeing social workers, no formal educational criteria set and no statutory limit on who might practise as a social worker (1995, p. 1). Noordegraaf (2007) would view such a professionalisation strategy as being driven from a neoliberal platform of management that is ultimately measured primarily in terms of its value for money, just as Coopers \& Lybrand did. The original professionalisation strategy, which was subsequently revised as a result of the evaluation, was devoid of any significant input from the profession. Rather, it reflected a preoccupation with management and service needs for evidence-based performance and accountability measured in outcome/output terms. However, the subsequent evaluation did set the scene for the eventual push by NZCYPS for statutory registration and research into the implications for NZCYPS (Ministry of Social Policy, 2000; NZCYPS, 1996). The motives of government for the statutory registration of social workers were derived from managerial and political imperatives that had been initially cloaked as a professionalisation strategy (NZCYPS, 1996).

\section{The political sponsorship of statutory registration}

By 1999, a momentum for statutory registration had emerged from separate agendas: the profession, through the inexorable march of the ANZASW with its aspirations for formal statutory recognition built upon its creditable system of selfregulation (Randal, 1997); and that of a government department, NZCYPS (1996), being nudged, under the oversight and direction of NPM, to shape up in terms of its practice standards and results. For statutory registration to become a reality, political sponsorship was needed for the requisite legislation to be introduced. This arose, courtesy of the NZLP (1999) in its party manifesto to "establish a system of professional registration for social workers that will cover the public and private sector" (1999, p. 509), and by subsequently being elected to form the New Zealand government in 1999. The NZLP's objective was brought into sharper focus by the recommendations of yet another review, this time of the Department of Child, Youth and Family Service (CYFS), (which had replaced NZCYPS). The ensuing report (Brown, 2000) was openly critical of NPM to which it assigned some responsibility for the continuing plight of CYFS social work services. The report cited the critique of Duncan and Worrall (2000) that attributed the undermining 
of the social work profession to managerially nuanced controls and expectations just as those documented in the 1989 Social Work Development Plan. The recommendations of the Brown report therefore became the catalyst for creating the legislative platform to honour the NZLP's manifesto proposal to introduce statutory registration. As the former Minister of Social Services and Employment recalled:

Judge Mick Brown's report did a very good job and highlighted a lot of the things, I guess, we are talking about here. So, yes, it gave us a pretty solid base to be saying, along with other things, arising from his report to say that there's something wrong here and we should be moving towards a more registered professional environment. (Interview in Randal, 2018)

The minister's concern had been with the growth in numbers of untrained and, as he saw it, unprofessional, social workers.

Social workers in the public sector had a pretty rough ride from the '80s onwards in the sense that they were constantly attacked, badly organised and felt very bad about the profession that they were in. (Interview in Randal, 2018)

The minister's personal commitment to foster the introduction of statutory registration as a vehicle to lift the status of social workers should also not be underestimated as a key factor in the enactment of the SWR Act in 2003. However, this should not be taken to imply that he regarded social workers as true professionals (Randal, 2018).

They [social workers] don't actually have all the bits and pieces and place to be a profession ... that's certainly true of social workers. They're still migrating towards that. And may not ever get there because they do include a large workforce of people ... that think of themselves as involved in this but aren't really ... they're not professionally involved. (Interview in Randal, 2018)

\section{Reflections on the enactment of statutory registration, 2014}

It would be excusable to assume that the ANZASW and the government were agreed regarding the desire for statutory registration for the social work profession. However, from the sample of association members who were re-interviewed in 2014 (Randal, 2018), the move to place social work in a regulatory context had both foreseen and unexpected as well as positive and negative consequences for the profession. Some had expected the ANZASW to be given a designated role in statutory registration or, at the very least, that membership of the association would be formally recognised somehow as a requirement for becoming registered. There were some misgivings that this did not occur. One interviewee stated:

I'm not clear that the Social Workers Registration Board have accorded the Association the mana that it deserved. I think the Social Workers Registration Board could have gone some way towards making it very highly desirable that you have your membership [as a requisite for statutory registration]. ( $R, 2014)$

Others saw it as a lost opportunity for the ANZASW and the Social Workers Registration Board (SWRB) to work together and promote social work in Aotearoa New Zealand. A consequence, seen by some, was a fractious relationship between the two bodies and the association displaced by the SWRB as leader of the profession. As foreseen, the concern was that the professional custodianship over social workers now lay with a statutory board bound to a political agenda and directly accountable to a minister of the Crown. The focus on economic rationalism, efficiency and risk management that such accountability could imply was regarded as being in tension with social work's value base of social justice and human rights.

I think you're right when you say there's "a new kid on the block". But this kids got 
huge backing, you know ... we've had to develop our sense of responsibility inside the profession. I think that that's ours always but I don't think we've got the same critical teeth. $(H, 2014)$

A particular concern, and unanticipated consequence, was that social workers were confused about the respective roles of the SWRB and ANZASW and, given the choice, would choose the accountability offered through statutory registration rather than membership of the association.

In 2013 an issue of the ANZASW journal was devoted "to provide some food for thought about the past decade and the changes that have occurred with social workers' registration" (O'Donoghue, 2013, p. 1). The reflections of a former president on the effects of social worker registration upon the ANZASW (Henderson, 2013) echoes some of the observations and sentiments expressed in the findings. These included "'thinking that the professional body would be a key driver and key part of state regulation" (2013, p. 60) and "there continues to be blurring of roles of the professional body and the regulatory authority" (2013, p. 67).

Given the twin commitments of both the ANZASW and the SWRB to fostering the professionalism of social workers, there was, nonetheless, the sense that the standing of, and confidence in, the profession had been raised. Apart from this, however, the consequences of the introduction of statutory registration, as viewed by the sample of association members, were mostly negative with the association seen as becoming sidelined, even overridden, as the leader of the social work profession in Aotearoa New Zealand (Randal, 2018).

\section{The theory of governmentality}

Foucault uses the term governmentality as a vehicle for describing how power is exercised, as an ensemble of institutions and procedures that are applied through the formation of government apparatuses and development of know-how and knowledge. It is, in some respects, a subtle process applying forms of expertise from a distance with the effect of fostering ways promoting new senses of security, welfare and selfresponsibility. Governmentality is achieved through the reinforcement and augmentation of existing technologies (Foucault, 1991; Gordon, 1991; Peters, 2001). In respect of the statutory registration of social workers governmentality can be evidenced in a number of respects.

The role of statutory social work includes practice assessment, social inquiry, surveillance as well as applying correction and discipline. With their statutory authority as public servants, social workers extend the state's capacity for governance - thus enabling the modern nation-state to govern the population (Webb, 2006, p. 51). Social work's role in policing families (Donzelot, 1980) and, in applying some of the "technologies" of government (Parton, 1999) gives weight to why a government agency would see the mantle of statutory registration as enhancing the identity and status of social workers as experts in their field (Parton, 1999) giving them further legitimacy in the eyes of other professionals and the public (Chambon, 1999). This also aligns with Wilson's (2009) observation that neoliberalism reinforces such a process with its push for personal/professional responsibility in meeting standards set by a regulatory body. Statutory registration attaches another source of authority to that derived by virtue of employment (Thibaud, 1972, as cited in Chambon, 1999, p. 91). Governmentality or the "conduct of conduct" is "to shape or regulate people's conduct according to certain principles or goals" (Parton, 1999, p. 104) and is, in a very practical sense, an aim of occupational regulation and statutory registration, to set the standards and ultimate accountabilities for engagement of the social worker with their client. Therefore, whoever sets the principles or goals for the practice of social work is integral to its governmentality (Randal, 2018). 
Risk management can also be viewed as being in accord with Foucault's governmentality (Foucault, 1991). Social work had always held a central expert mediating role (Chambon, 1999; Webb, 2006) between society and state in the administration of the welfare state often with prescribed statutory responsibilities. Social work was the broker between needs / clients and social resources/services. But with the gradual introduction of managerialist doctrines under NPM (Harris, 2003; Hood, 1991; Hood \& Scott, 2000) government social work services were compelled to become far more focused upon performance and accountability. So in addition to improving financial efficacy, there was also the need to minimise any embarrassing consequences at practice, management and policy levels to cover and account for dangerous situations, perceived practice failure and the unpredictabilities sometimes encountered. Described as "actuarial governance" (Webb, 2006, p. 5, 134ff) the responsibility was placed on the practitioner to ensure that risk was covered, or at the least, monitored and explainable through reporting and audit associated with the prevailing "performance management and audit culture" (2006, p. 180). Therefore, the introduction of statutory registration can be viewed as part of the government's risk management strategy that holds social workers to account for their practice (Webb, 2006).

\section{Applying the theory of governmentality}

The form of regulation applied to the statutory registration of social workers is also illustrative of the application of governmentality from a distance with the SWRB effectively shaping the professional behaviour of social workers through the criteria, processes and oversight set for social workers. This fulfils one of the three general characteristics of regulation of public sector services (Hood \& Scott, 2000). Secondly, there is an arm's length separation between the SWRB, as a Crown entity (New Zealand Treasury, 2014), and the body of social workers subject to regulation; and thirdly, the SWRB has the statutory authority and mandate to assess and maintain the statutory register of social workers (Hood \& Scott, 2000; Webb, 2006). As a mechanism of the regulatory state, statutory registration sets the rules for acceptable social work practice. Furthermore, it monitors and enforces the rules almost as if all social workers are members of the public service. Despite the arms-length separation between the regulator and the regulatee (the social worker) by virtue of the Crown entity status accorded the SWRB, the relational distance between the regulator and regulatee is otherwise close (Hood \& Scott, 2000). The SWRB includes six registered social workers. It is claimed that regulators and regulatees from the same milieu would lead to more effective regulation - applying the adage "former poachers make the best gamekeepers" - as they talk the same language and "know where the bodies are buried" (2000, p. 10). This illustrates a subtle application of governmentality, using the subjects of statutory registration (registered social workers), to also form and enforce its rules. The six social workers appointed by the minister to the inaugural SWRB held significant roles in the ANZASW. This was observed by some as a conflict of interest and their appointments to the SWRB as a generous endowment by the association (Randal, 2018). Working relationships between those appointees and the association, particularly at the outset, were recalled as being at times fraught, even adversarial and antagonistic, and contrary to expectations that the relationship would be collegial (Randal, 2018).

While a close relational distance between the regulator and regulatees is expected to result in more effective regulation, clearly this does not always guarantee a smooth relationship at organisational and personal levels, especially where one, the ANZASW, is regarded as having generously endowed the other, the SWRB, with personnel and processes. Governmentality plays out in many ways. 


\section{The government agenda, 2017}

Underlying the government agenda is that, as the main employer of social workers in services for children and families, and in health and education, it can claim a legitimate interest in "providing mechanisms to ensure that social workers are competent and fit to practise and accountable for the way in which they practise" (SWRB, 2017a, $2017 \mathrm{~b})$. Thus, the stance that the government takes in respect of statutory registration is as an employer. Its agenda was also grounded in the ethos and thrust of public sector reform related to the managerial control of professional work (Uttley, 1994). Not all Ministry for Children Oranga Tamariki (MCOT; previously CYFS) social workers belong to the association and thereby able to claim the representation that a professional association offers and be accountable to particular standards and ethics that enhance professionalism (Noordegraaf, 2016). As a public profession, they have very little wherewithal to fall back on to resist the managerial frameworks and scrutiny foisted upon them (Randal, 2018).

Recent developments now see the wider profession in conflict with the government over what constitutes "social work." In 2017 a Social Workers Registration Legislation Bill (the SWRL Bill) was introduced into parliament aimed at continuing to enhance the professionalism of social workers by extending existing legislation to make statutory registration mandatory (SWRL Bill, 2017, p. 2). However, in its present form the Bill has been described by the Public Service Association (PSA), an industrial union representing many state social workers, as "an assault on the profession" and "an arbitrary and ineffectual protection of title and role" given that the Bill fails to define social work in terms of a defined scope of practice (PSA, 2017, p. 6). Instead, the SWRL Bill seeks to have the determination of social work rest on the position descriptions ascribed by employers for any positions titled "social worker" (SWRL Bill, 2017, §§s 6AAA, 6AAB). Ross
(2017, p. 1) contends that this "embeds long standing misunderstanding of and disrespect for social work as a unique and skilled profession". The ANZASW has indicated its intention to "work to protect the profession of social work" and address its concerns that the Bill only seeks to register the title "social worker" (ANZASW, 2017a, 2017c, p. 10; Sandford-Reed, 2017). The SWRB shares similar concerns about the proposal (SWRB, 2017b, p. 13; Walker, 2017). The fact that the PSA, the ANZASW and the SWRB view the SWRL Bill similarly and have separately expressed their concerns forcefully and publicly points to an intriguing new phase for the profession and its relationship with the state.

By February 2018 the parliamentary Social Services and Community Committee had received 60 submissions regarding the merits of the SWRL Bill. In particular, the majority of the submitters found $\S 6 \mathrm{AAB}$ of the Bill problematic in that defining "practising as a social worker" is determined by the employer. According to one submitter, an unintended interpretation of $\S 6 \mathrm{AAB}(\mathrm{d})$ was that it could make registration mandatory for all members of ANZASW, given that they are members of an organisation that is described using the words "social worker." The strong recommendation from the majority of submitters was that the definition instead be based on the specific scope of social work being defined (SWRL Bill, 2018).

Given the views held in the sample of ANZASW members in respect of the original legislation, it would appear that the government's current views and agenda for the social work profession remain unchanged; this seems premised on an inherent lack of confidence and trust in the profession. The government seems determined to continue to control the profession by not respecting the globally accepted definition of social work (IFSW, 2014) as the basis for statutory registration "to protect the safety of members of the public" (SWRB, 2017a). Rather, the government prefers, as intimated in the SWRL Bill, to leave this to the various position 
descriptions for social workers, the majority of whom are employed in government social work services or in non-government organisations (NGOs), most of which have ties to government funding contracts. Of 6,472 registered social workers (as at September 2017), 51\% were employed in public (government) social work services (MCOT, District Health Boards, Education), 27\% employed in NGOs, $18 \%$ were Not Practising and $4 \%$ were Self Employed (SWRB, 2017b, p.10).

\section{Conclusions}

The foregoing analysis of what led to the introduction of statutory registration for social workers in Aotearoa New Zealand contrasts the different aspirations, expectations and outcomes sought. On the one hand, and as sought, the government has achieved a means for providing added assurance in respect of the quality of social work practice undertaken by registered social workers through the identification of practice standards and qualifications, the periodic assessment of competence and the means for complaints to be dealt with. On the other hand, in supporting the introduction of statutory registration, the ANZASW has enhanced opportunities for the social work professional to gain another string to their bow should they choose to be registered and a member of the association. The ANZASW has also maintained its absolute independence as a professional body avoiding any contamination should it have become formally associated with the process of statutory registration in some way. The whole process, as it has played out, has served to exemplify, however, the extent to which the state, through its government ministries, has exercised its power through and over the social work profession and thereby given strength to its overall governmentality. "What this effective monopoly means is that Parliament - which has demonstrated that as a body it has a quite limited view of social work as an independent profession - is entirely in control of the present and future of social work" (Henrickson, 2018, p. 1).
There have been gains and losses. A cynical analysis could be made of the early gains made in support of the implementation of statutory registration at the expense of the ANZASW. Clearly, the initial close relational distance between the SWRB and the association provided statutory registration with an initial stamp of professional integrity. This endowment carried through to the adaptation, utilisation and initial reliance upon processes, such as competency assessment, that had been initiated by the ANZASW. The association also lost its role in the accreditation of social work educational qualifications. There has also been an impact on ANZASW membership. Choosing to opt for statutory registration through the SWRB has been a commonly cited reason for resignation from the association (ANZASW, 2017b). Membership of the ANZASW has a lower priority for social workers employed by MCOT. In September 2017 there were 1,445 registered social workers employed by MCOT (SWRB, 2017b, p. 10). At the same time there were 818 MCOT social workers who were members of the association (ANZASW, 2017c, p. 9).

The fear must be that the introduction of new legislation (SWRL Bill, 2017), in the name of enhancing professionalism and making statutory registration mandatory, will only perpetuate the government's hold over the profession with the risk of the ANZASW losing ground as the professional custodian of social work practice in Aotearoa New Zealand.

Acknowledgement: The author acknowledges the support of the University of Otago, by means of the University of Otago Postgraduate Publishing Bursary (Master's).

\section{References}

Anleu, S. L. R. (1992). The professionalisation of social work? A case study of three organisational settings. Sociology, 26(1), 23-43.

Aotearoa New Zealand Association of Social Workers (ANZASW). (2017a).Mandatory Social Worker Registration Bill [Press release]. Retrieved from http:// www.scoop.co.nz/stories/BU1708/S00598/mandatorysocial-worker-registration-bill.htm

Aotearoa New Zealand Association of Social Workers (ANZASW). (2017b). ANZASW Annual Reports. 
Retrieved from https://anzasw.nz/anzasw-annualreports/

Aotearoa New Zealand Association of Social Workers (ANZASW). (2017c). ANZASW Briefing to Incoming Ministers. Retrieved from https://anzasw.nz/wp-content/ uploads/ANZASW-Briefing-to-Incoming-MinistersSep17.pdf

Balthazard, C. (2016). What does it mean to be a regulated profession? Regulatory Affairs Human Resources Professionals Association. Retrieved from https://www. hrpa.ca/Documents/Regulation/Series-on-Governance/ What\%20it\%20means\%20to\%20be\%20a\%20regulated\%20 profession\%20September\%201,\%202017.pdf

Beddoe, L., \& Randal, H. (1994). The New Zealand Association of Social Workers: The professional response to a decade of change. In R. Munford \& M. Nash (Eds.), Social work in action (pp. 21-36). Palmerston North, New Zealand: The Dunmore Press.

Blagdon, J., Taylor, M. \& Keall, B. (1994). Update on social worker registration. Social Work Review, 5(4), 24-25.

Brown, M. J. A. (2000). Care and protection is about adult behaviour. Wellington, New Zealand: New Zealand Government

Chambon, A. S. E. (1999). Reading Foucault for social work New York, NY: Columbia University Press.

Cockburn, G. (1994). The Children, Young Persons and their Families Act 1989: Past, present and future. In R. Munford \& M. Nash (Eds.), Social work in action (pp. 85-103). Palmerston North, New Zealand: The Dunmore Press.

Coopers \& Lybrand. (1995). Evaluation of professionalisation strategy. Wellington, New Zealand: Children and Young Persons Service (CYPS).

Corrigan, R., Semmons, W., Clark, K., Taylor, M., McPherson, C., Cromie, B., ... Randal, H. (1999). Statutory registration of social workers: The Registration Project team. Social Work Review, 9(4), 18-23.

Donzelot, J. (1980). The policing of families: Welfare versus the state. London, England: Hutchinson \& Co.

Duncan, G., \& Worrall, J. (2000). Window on the world. Social policy and social work in New Zealand. European Journal of Social Work, 3(3), 283-295. https://doi.org/10.1080/714052831

Foucault, M. (1991). Governmentality. In G. Burchell, C. Gordon, \& P Miller (Eds.), The Foucault effect: Studies in governmentality (pp. 87-104). Chicago, IL: University of Chicago Press.

Fraser, S., \& Briggs, L. (2016). Bi-culturalism and accountability: Fundamental changes in social work practice in Aotearoa New Zealand 1984-1990. Aotearoa New Zealand Social Work, 28(1), 43-51.

Gilbert, T., \& Powell, J. L. (2010). Power and social work in the United Kingdom. Journal of Social Work, 10(1), 3-22. doi: https://10.1177/1468017309347237

Gordon, C. (Ed.). (1991). Government rationality: An introduction. Chicago IL: University of Chicago Press.

Harris, J. (2003). The social work business. London, UK: Routledge.

Healy, K. (2000). Rethinking professional power and identity. In SAGE (Ed.), Social work practices: Contemporary perspectives on change (pp. 71-94). London, UK: SAGE.

Henderson, R. (with O'Donoghue, K.). (2013). A former president reflects on the effects of social worker registration upon the association: An interview with Rose Henderson. Aotearoa New Zealand Social Work, 25(3), 60-67.

Henrickson, M. (2018). Parliamentary submissions Re: Social Workers Registration Bill. https://www.parliament. nz/resource/en-NZ/52SCSS_EVI_74844_363/ d5bcb06a43c5ebea6b3308868b96ac1f69bdd21a

Hessey, E. (1983, April). NZASW Newsletter - Registration. News and Views in Social Work: A national newsletter.

Hood, C. (1991). A public management for all seasons? Public Administration, 69(1), 3-19. doi:10.1111/j.1467-9299.1991.tb00779.x

Hood, C., \& Scott, C. (2000). Regulating government in a "managerial" age: Towards a cross-national perspective. London, UK: Centre for Analysis of Risk and Regulation, London School of Economics and Political Science.

Howe, E. (1980). Public professions and the private model of professionalism. Social Work, 25(3), 179-191.

Hunt, S. (2016). The social work professionalisation project before the 1990s in Aotearoa New Zealand: The dream. Aotearoa New Zealand Social Work, 28(3), 15-25. doi:10.11157/anzswj-vol28iss3id245

Interim Board of Competency. (1990). Competent social work practice. New Zealand Association of Social Workers (Inc). Christchurch, New Zealand

International Federation of Social Workers (IFSW. (2014). Global definition of social work. Retrieved from http:// ifsw.org/policies/definition-of-social-work/

Jones, C. J. (1979). Social work: The reluctant profession (Unpublished Masters Thesis). University of Auckland, New Zealand.

Jones, P. R. (1974). Social work - A profession? The New Zealand Social Worker: News and Opinions, 10(1), 27-37.

Keall, B.; Te Kowhai-Rennie, M., \& Quivooy, M. (1989). Social work development plan 1989. Te Aaa hou: The new path. Wellington, New Zealand: Department of Social Welfare.

Mason, K. H. (1992). Review of the Children, Young Persons and their Families Act 1989. Wellington, New Zealand: Department of Social Welfare.

Matarazzo, J. (1977). Higher education, professional accreditation, and licensure. American Psychologist, 32, 856-858.

McCreary, J. R. (1964). Keynote address. Paper presented at the NZASW Inaugural Conference 1964. New Zealand Association of Social Workers (NZASW), Auckland.

Ministry of Social Policy (MoSP). (2000). Registration of social workers discussion paper. Wellington, New Zealand: Author.

Nadesan, M. H. (Ed.). (2008). Governmentality, biopower, and everyday life. [e-book]. Hoboken, NJ: Taylor \& Francis.

New Zealand Association of Social Workers (NZASW). (1964). Constitution of the New Zealand Association of Social Workers (Incorporated). Auckland, New Zealand: Author.

New Zealand Association of Social Workers (NZASW). National Executive. (1976). Registration. News and Views in Social Work: A national newsletter. December. Auckland, New Zealand: Author.

New Zealand Association of Social Workers (NZASW). (1978). Minutes, Special General Meeting. Massey University: Author.

New Zealand Association of Social Workers (NZASW). (1981a). Letters to the Editors: Rumours. News and 
Views in Social Work: A national newsletter. (August), p. 4. Auckland, New Zealand: Author.

New Zealand Association of Social Workers (NZASW). (1981b). Grapevine talk "Mrs Anonymous". News and Views in Social Work: A national newsletter. (June), p. 11 Auckland, New Zealand: Author.

New Zealand Association of Social Workers (NZASW). (1984). Discussion paper on "Registration". Auckland, New Zealand: Author.

New Zealand Children and Young Persons Service (NZCYPS). (1996). Professionalisation strategy. Wellington, New Zealand: Department of Social Welfare.

New Zealand Labour Party (NZLP). (1999). Key policies 1999: The future is with Labour. Wellington, New Zealand: Author.

New Zealand Treasury. (2017). Crown entities. Retrieved from http://www.treasury.govt.nz/statesector/crownentities

Noordegraaf, M. (2007). From "pure" to "hybrid" professionalism: Present-day professionalism in ambiguous public domains. Administration \& Society, 39(6), 761-785.

Noordegraaf, M. (2016). Reconfiguring professional work. Administration \& Society, 48(7), 783-810. doi:10.1177/0095399713509242

O'Donoghue, K. (2013). Editorial: The Social Workers Registration Act (2003) - 10 years on. Aotearoa New Zealand Social Work, 25 (3).

Parton, N. (1999). Reconfiguring child welfare practices: Risk, advanced liberalism and the government of freedom. In A. S. Chambon, A. Irving, \& L. Epstein (Eds.), Reading Foucault for social work. New York, NY: Columbia University Press.

Peters, M. (2001). Poststructuralism, Marxism, and neoliberalism between theory and politics. Lanham, MD: Rowman \& Littlefield.

Pitt, L. (2005). Social work registration: Knowledge and power. Social Work, 17(3), 41-42.

Powell, J. L. (2014). Foucault, professional social work and power. African Journal of Social Sciences, 4(4), 1-16.

Public Service Association (PSA). (2017, September). Social Work Bill an assault on the profession. Working Life.

Randal, H. (1997). Competent practice and its regulation - Debating the issues around the registration of social work in New Zealand. Social Work Review, March/June 9 (1 \& 2), 16-19.

Randal, H. (2018). There's a new kid on the block (Masters thesis). University of Otago. Retrieved from http://hdl.handle.net/10523/7812

Ross, A. (2017). The Social Workers Registration Bill: A call to action! Retrieved from http://www. reimaginingsocialwork.nz/2017/08/the-social-workersregistration-bill-a-call-to-action/

Sandford-Reed, L. (2017). From the chief executive. ANZASW Noticeboard Kete (36), 6-8. Retrieved from https://anzasw.nz/noticeboard-kete/

Social Workers Legislation Bill. (2017). Retrieved from http://swrb.govt.nz/about-us/news-and-publications/ publications/

Social Workers Legislation Bill. (2018). Retrieved from https:// www.parliament.nz/en/pb/bills-and-laws/bills-proposedlaws/document/BILL_74844/tab/submissionsandadvice
Social Workers Registration Act. (2003). Retrieved from http://www.legislation.govt.nz/act/public/2003/0017/ latest/DLM189915.html

Social Workers Registration Board. (2017a). About us. Retrieved from http://swrb.govt.nz/about-us/

Social Workers Registration Board. (2017b). Briefing for the incoming Minister of Social Development. Retrieved from https://www.beehive.govt.nz/sites/default/files/2017-12/ Social\%20Workers\%20Registration\%20Board.pdf

Uttley, S. (1994). Professionals "moving down": Rationalisation, routinisation and development. Paper presented at the Advances in Social Work and Welfare Education, Perth, Western Australia.

Walker, S. (2017, September). View from the chair. Onboard. Newsletter of the Social Workers Registration Board. Retrieved from http://swrb.govt.nz/about-us/news-andpublications/publications/

Webb, S. A. (2006). Social work in a risk society: Social and political perspectives. Basingstoke, England: Palgrave Macmillan.

Wilson, C. (2009). Beyond state politics: Subjectivities and techniques of government in contemporary neoliberal social movements. In S. Binkley \& J. Capetillo Ponce (Eds.), A Foucault for the twenty first century (pp. 30-44). Newcastle upon Tyne, UK: Cambridge Scholars. 